\title{
Pelaksanaan Undang-Undang Nomor 7 Tahun 2017 tentang Pemilihan Umum (Studi Terhadap Pemutakhiran Data Pemilih dalam Pemilukada di Kabupaten Bone)
}

\author{
Delviani \\ Institut Agama Islam Negeri (IAIN BONE) \\ Delvianihtniainbone@gmail.com
}

\begin{abstract}
Abstrak
Penelitian ini bertujuan untuk mngetahui Pelaksanaan Undang-Undang Nomor 7 Tahun 2017 tentang Pemilihan terhadap Pemutakhiran Data Pemilih dalam Pemilukada Tahun 2018 di Kabupaten Bone. Untuk memperoleh data dari masalah tersebut, penulis menggunakan jenis penelitian lapangan dengan pendekatan yuridis normatif dan pendekatan yuridis empiris serta melakukan observasi dan wawancara. Data yang diperoleh kemudian diolah dengan menggunakan metode analisis data kualitatif untuk menganalisis terkait pemutakhiran data pemilih dalam pemilukada Tahun 2018 di Kabupaten Bone. Hasil penelitian tersebut menunjukkan bahwa pelaksanaan Undang-Undang Nomor 7 Tahun 2017 tentang Pemilihan Umum dalam Pemiliukada di Kabupaten Bone telah berjalan dengan baik namun belum terlaksana dengan sempurna. Hal tersebut terjadi karena adanya sejumlah anggota masyarakat yang masih belum memiliki Kartu Tanda Penduduk (E-KTP) dan adanya sejumlah masyarakat yang tidak berada di rumah pada saat proses pemutakhiran data pemilih dilaksanakan sehingga pemutakhiran data pemilih tersebut tidak berjalan sesuai dengan waktu yang telah ditentukan.
\end{abstract}

Kata Kunci : Undang-Undang Nomor 7 Tahun 2017 tentang Pemilihan Umum di Kabupaten Bone

\section{Pendahuluan}

demokrasi telah menjadi bagian penting dalam interaksi antar sesama manusia. Sekalipun demokrasi berasal dari tradisi barat, ia telah menjadi wadah global. Hampir dapat dipastikan tidak ada satupun negara di dunia ini yang sepi dari tuntutan demokrasi. Meskipun penerapan demokrasi tidaklah seragam pada masingmasing kawasan di dunia, demokrasi telah menjadi media bagi masyarakat dunia 
untuk mengekspresikan kebebasan individu dan hak-haknya sebagai warga negara. Menurut Abraham Lincoln demokrasi yaitu suatu pemerintahan dari rakyat, oleh rakyat dan untuk rakyat. ${ }^{102}$

Salah satu faktor penting bagi keberhasilan penyelenggaraan pemilihan umum terletak pada kesiapan dan profesionalitas penyelenggara pemilihan umum itu sendiri, yaitu Komisi Pemilihan Umum (KPU), Badan Pengawas Pemilu (BPP), dan Dewan Kehormatan Penyelenggara Pemilu (DKPP) sebagai satu kesatuan fungsi penyelenggara. Ketika konstitusi ini telah diamankan oleh Undang-Undang untuk menyelenggarakan pemilihan umum menurut fungsi, tugas dan kewajibannya masing-masing. ${ }^{103}$

Partisipasi politik dalam negara demokrasi merupakan indikator implementasi penyelenggaan kekuasaan negara tertinggi yang absah oleh rakyat yang dimanifestasikan dengan keterlibatan mereka dalam pesta demokrasi. Semakin tinggi tingkat partisipasi politik mengindikasikan bahwa rakyat mengikuti dan memahami serta melibatkan diri dalam kegiatan kenegaraan. Sebaliknya tingkat partisipasi politik yang rendah pada umumnya mengindikasikan bahwa rakyat kurang menaruh apresiasi atau minat terhadap masalah atau kegiatan kenegaraan. Seiring dengan sikap partisifatif pemilih yang menggunakan hak pilihnya, sikap golongan putih (golput) yang tidak partisifatif yang menggunakan hak pilihnya dalam pemungutan suara menjadi indikator dari tingkat keberhasilan pemilihan umum yang demokratis. ${ }^{104}$

Bukan hanya dari segi hukum secara umum yang mengharuskan kita untuk selalu taat dalam aturan sesuai yang di atur dalam Undang-Undang bahkan dalam Islampun menegaskan tentang pentingnnya menggunakan hak pilih dan menyampaikan amanat kepada mereka yang berhak menerimanya sebagaimana yang menjadi dasar di keluarkannya fatwa Majelis Ulama Indonesia (MUI) pada tanggal 25 Januari 2009, ketika Majelis Ulama Indonesia melakukan Sidang Ijtima' yang ke-III yang di gelar di Padang Panjang, Sumatera Barat. Berdasarkan hasil sidang yang dihadiri sekitar 750 orang ulama tersebut, disepakati lima point pada Keputusan Sidang Ijtima' Komisi Fatwa Majelis Ulama Indonesia tentang Masail Asasiyah

102 A. Ubaidillah dan Abdul Rozok, Pancasila, Demokrasi, HAM, dan Masyarakat Madani, Edisi Revisi, (Cet. VIII; Jakarta:Prenada Media, 2012), h. 65

${ }^{103}$ Undang-Undang Nomor 7 Tahun 2017 tentang Pemilihan Umum

104 Orang-orang yang tidak Memberikan Hak Suaranya Dalam Pemilihan Umum, Jurnal, Soebagio, Implikasi Golongan Putih dalam Persfektif Pembangunan Demokrasi Indonesia, Tanggerang, 2008, h. 4 
Wathaniyyah (masalah strategis bengsa) point IV dalam Penggunaan Hak Pilih dalam Pemilihan Umum yang isinya sebagai berikut:

1. Pemilihan umum dalam pandangan Islam adalah upaya untuk memilih pemimpin atau wakil yang memenuhi syarat-syarat ideal bagi terwujudnya cita-cita bersama sesuai dengan aspirasi umat dan kepentingan bangsa.

2. Memilih pemimpin dalam Islam adalah kewajiban untuk menegakkan imamah dan imarah dalam kehidupan bersama.

3. Imamah dan imarah dalam Islam menghajatkan syarat-syarat sesuai dengan ketentuan agama agar terwujud kemaslahatan dalam masyarakat.

4. Memilih pemimpin yang beriman dan bertaqwa, jujur, terpercaya, aktif, dan aspiratif, mempunyai kemampuan, serta memperjuangkan kepentingan umat Islam hukumnya adalah wajib. ${ }^{105}$

Dasar hukum dikeluarkannya Fatwa Majelis Ulama Indonesia (MUI) yaitu terdapat dalam Q.S An-Nisa [4]:58

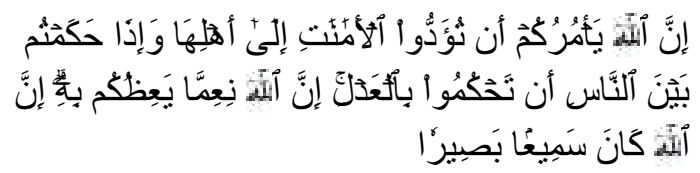

Terjemahan: Sesungguhnya Allah menyuruh kamu menyampaikan amanat kepada yang berhak menerimanya, dan (menyuruh kamu) apabila menetapkan hukum di antara manusia supaya kamu menetapkan dengan adil. Sesungguhnya Allah memberi pengajaran yang sebaik-baiknya kepadamu. Sesungguhnya Allah adalah Maha Mendengar lagi Maha Melihat.

Adapun penjelasan terkait dengan terjemahan dari Q.S An-Nisa ayat 58 yaitu bahwa amanat itu ialah ketika kita menanggung sesuatu yang menjadi milik orang lain dan kita yang bertanggung jawab mengembalikan hal tersebut adalah suatu kewajiban bagi kita ketika menanggung amanat untuk mengembalikan kepada pemiliknya. Bukan lantaran kita dihianati, kemudian membuat kita diperbolehkan menghianati juga. Dan dikatakan juga bahwa segala sesuatu yang dipercayakan kepada manusia dan diperintahkan untuk dikerjakan. Dalam ayat ini, Allah SWT memerintahkan hambanya untuk menyampaikan amanat secara sempurna, utuh, tanpa mengulur-ulur atau menunda-nundanya kepada yang berhak menerimanya. ${ }^{106}$

\footnotetext{
${ }^{105}$ Fatwa Majelis Ulama Indonesia tentang Masail Asasiyah Wathaniyyah (masalah strategis bengsa) point IV dalam Penggunaan Hak Pilih dalam Pemilihan Umum

${ }^{106}$ Departemen Agama RI, Al-Qur'an dan Terjemahannya, Q.S. An-Nisa: 58

Jurnal Al-Dustur; VOLUME 1 NO 1, DESEMBER 2018
} 
Sementara pada tahap penyelengaraan pemilihan umum salah satu aspek yang menjadi isu krisis dalam menilai apakah pemilihan umum dapat dilaksanakan secara jujur dan adil adalah pendaftaran pemilih. Demi menghasilkan kualitas daftar pemilih, Komisi Pemilihan Umum harus dapat memastikan semua pemilih terdaftar dalam Daftar Pemilih Tetap melalui mekanisme pemutakhiran dan penyusunan daftar pemilih. Dalam hal ini, mulai dari petugas pemutakhiran data pemilih di tingkat yang paling bawah hingga Komisi Pemilihan Umum wajib memastikan akurasi data pemilih sesuai dengan dengan kondisi faktual pemilih dan bersih dari pemilih ganda. Semakin kecil jumlah pemilih yang tidak terdafar dalam Daftar Pemilih Tetap, maka dapat dikatakan kualitas daftar pemilih akan semakin baik. ${ }^{107}$

Masalah kualitas dan akurasi Daftar Pemilih Tetap menjadi tanggung jawab bersama para pemangku kepentingan pemilu seperti Komisi Pemilihan Umum, Kementerian Dalam Negeri (Kemendagri), Kementerian Luar Negeri (Kemenlu) dan partisipasi aktif dari seluruh lapisan masyarakat. Seluruh pemangku dalam pemilu turut serta dalam memberi andil yang sangat besar untuk dapat mewujudkan akurasi dan kualitas Daftar Pemilih Tetap.

Pemutakhiran data pemilih merupakan salah satu agenda wajib yang harus dilaksanakan oleh pihak Komisi Pemilihan Umum baik KPU Provinsi maupun KPU Kabupaten/Kota menjelang diselenggarakannya pemilihan umum untuk menghindari terjadinya kekeliruan pada saat pemungutan suara sedang berlangsung akan tetapi pada kenyataannya Data Potensil Pemilih Pemilu tersebut dinilai masih belum merupakan data terkini karena di dalamnya masih terdapat pemilih yang sudah meninggal dunia, alih status sebagai TNI/Polri atau pemilih yang telah pindah domisili atau bahkan yang menjadi daftar pemilih ganda khususnya pada Pemilihan Umum Kepala Daerah di Kabupaten Bone. Berdasarkan semua penjelasan di atas mendorong penulis untuk menulis skripsi ini dengan judul "Pelaksanaan UndangUndang Nomor 7 Tahun 2017 tentang Pemilihan Umum (Studi Terhadap Pemutakhiran Data Pemilih dalam Pemilukada Tahun 2018 di Kabupaten Bone)".

107 Subekti, Ramlan, dkk, Meningkatkan Akurasi Daftra Pemilih dan Mengatur Kembali Sistem Pemilih Pemutakhiran Daftra Pemilih, ([t. Ed]), (Jakarta: Kemitraan Bagi Pembaruan Tata Pemerintahan, 2011), h. 22 


\section{Rumusan Masalah}

Berdasarkan latar belakang di atas, penulis menetapkan rumusan masalah. Adapun rumusan masalah yang dimaksudkan tersebut adalah:

1. Bagaimana pelaksanaan Undang-Undang Nomor 7 Tahun 2017 tentang Pemilihan Umum dalam pemutakhirkan data pemilih dalam pemilukada tahun 2018 di Kabupaten Bone?

2. Bagaimana kendala yang di hadapi oleh Komisi Pemilihan Umum Kabupaten Bone dalam pemutakhirkan data pemilih dalam pemilukada Tahun 2018 di Kabupaten Bone?

\section{Definisi Operasional}

Untuk menghindari kekeliruan dalam memahami makna yang terkandung dalam skripsi ini, penulis merasa perlu memberikan pengertian kata yang terdapat pada judul skripsi ini.

Pelaksanaan merupakan sebuah penerapan atau orang melaksanakan. ${ }^{108}$

Pemilihan umum adalah suatu sarana bagi masyarakat untuk ikut serta dalam memberikan suaranya guna memilih wakil rakyat serta merupakan bukti adanya uapaya untuk mewujudkan demokrasi. ${ }^{109}$

Pemutakhirkan adalah membuat jadi mutakhir, membasukan atau memodernkan. ${ }^{110}$

Data adalah sebuah keterangan yang benar dan nyata. ${ }^{111}$

Pemilih adalah orang yang memilih atau yang melakukan pemilihan. ${ }^{112}$

Pemilukada adalah sarana pelaksanaan kedaulatan rakyat di Provinsi dan Kabupaten/Kota untuk memilih Gubernur, Bupati/Walikota berdasarkan Pancasila dan Undang-Undang Dasar Negara Revublik Indonesia Tahun 1945. ${ }^{113}$

108 Tim Pustaka Agung Harapan, Kamus Ilmiah Populer, ([t.Ed]), ((Cet. 2, Surabaya: Cv Pustaka Agung Harapan, ([t.Th])), h. 222

${ }^{109}$ Muhadam Labolo, Teguh Ilham, Partai Politik dan Sistem Pemilihan Umum di Indonesia, Ed. 1, (Cet. 1; Jakarta:Rajawali Pers, 2015), h. 50

${ }^{110}$ Pusat Bahasa (Pusba), Kamus Besar Bahasa Indonesia Ed. 3. Dikutip pada laman Website http//www. KamusBesar.com/Memutakhirkan, Hari Selasa, 08-08-2017, pukul 06:25 Wib

${ }^{111}$ Pusat Pembinaan dan Pengembangan Bahasa, Kamus Besar Bahasa Indonesia, Ed. 2, (Cet. 3;Jakarta: Balai Pustaka, 1994), h. 211

112 Pusat Pembinaan dan Pengembangan Bahasa, Kamus Besar Bahasa Indonesia, h. 769

113 Srikandi Rahayu, Pengertian Pilkada atau Pemilukada, Dikutip pada laman website, http://seputarpengertian.blogspot.co.id/pengertian-pilkada-ataupemilukada.htmlDiakses pada hari Rabu 09-08-2017, pukul 20:30 
Berdasarkan pengertian judul di atas, maka defenisi operasional judul adalah bagaimana bentuk dari pelaksanaan dari Undang-Undang Nomor 7 Tahun 2017 tentang Pemilihan Umum dalam pemutakhirkan data pemilih dalam pemilukada tahun 2018 di Kabupaten Bone.

\section{Tujuan dan Kegunaan Penelitian}

a. Tujuan

Berdasarkan rumusan masalah tersebut, maka tujuan penelitian yang ingin dicapai oleh penulis dalam penelitian ini adalah sebagai berikut:

1. Untuk mengetahui bagaimana implementasi dari Undang-Undang Nomor 7 Tahun 2018 tentang Pemilihan Umum dalam pemutakhirkan data pemilih dalam pemilukada tahun 2018 di Kabupaten Bone.

2. Untuk mengetahui upaya apa saja yang dilakukan oleh Komisi Pemilihan Umum (KPU dalam memutakhirkan data pemilih dalam pemilukada tahun 2018 di Kabupaten Bone.

b. Kegunaan

Dengan tercapainya tujuan penelitian sebagaimana yang telah penulis uraikan di atas, maka hasil penelitian tersebut diharapkan berguna untuk:

1. Kegunaan ilmiah, yakni hasil penelitian ini diharapkan dapat memberikan kontribusi dalam mengembangkan ilmu pengetahuan agar nantinya dapat menjadikan negara ini sebagai negara yang memiliki wawasan yang luas.

2. Kegunaan praktis, yakni hasil penelitian diharapkan dapat memberi pemikiran dan pemasukan terhadap individu, kelompok, dan instansi yang terkait dalam merumuskan kebijakan masyarakat, bangsa, negara, dan agama agar nantinya tercipta kehidupan yang tentram dan tertib.

\section{Tinjauan Pustaka}

Dalam penelitian ini penulis juga menggunakan penelitian-penelitian terdahulu yang dianggap relevan dengan judul sebagai bahan referensi untuk penulis dan dapat di lihat dan uraikan di bawah ini:

1. Dhoni Rozitra dalam tesis Evaluasi dan Implementasi Menejemen dalam Pemutakhiran Data Pemilih (Studi pada Pemilihan Legislatif Tahun 2014 oleh Komisi Pemilihan Umum Kota Palembang), Program Pasca Sarjana Magister Ilmu Pemerintahan Fakultas Sosial dan Ilmu Politik Universitas Lampung, Bandar Lampung 2017. Dalam penelitian ini peneliti fokus hanya membahas 
mengenai evaluasi yang dilakukan oleh Komisi Pemilihan Umum Kota Palembang dalam pemutakhiran data pemilih dengan menggunakan sistem menejemen. ${ }^{114}$

2. Evi Juliansyah (2011) dalam jurnal dengan judul Implementasi Kebijakan Pemutakhiran Administrasi Pemilih dalam Pemilihan Gubernur dan Wakil Gubernur. Dalam penelitian, peneliti ini berfokus pada proses pemutakhiran data pemilih. Penelitian tersebut hanya melihat dari proses pemutakhiran data pemilih di lapangan dengan tidak membahas sistem yang dipakai untuk melakukan pemutakhiran data pemilih seprti adanya data pemilih ganda, adanya daftar pemilih yang telah meninggal dunia namun masih terdaftar sebagai daftar pemilu tetap. ${ }^{115}$

Berdasarkan dari kedua bentuk penelitian di atas, penulis dapat menarik sebuah kesimpulan yaitu meskipun dari kedua penelitian tersebut dengan penelitian yang akan dilakukan oleh penulis memiliki kesamaan yaitu berfokus pada implementasi atau pelaksanaan mengenai pemutakhiran data pemilih namun penulis juga akan mengkaji mengenai upaya yang dilakukan oleh Komisi Pemilihan Umum Kabupaten Bone sehingga penerapan dari undang-undang tersebut tidak bisa berjalan dengan sebagaimana mestinya.

\section{Kerangka Fikir}

Berdasarkan uraian yang telah dikemukakan sebelumnya, maka pada bagian ini diuraikanlah kerangka berfikir yang dijadikan sebagai landasan berfikir dalam melaksanakan penelitian. Pada dasarnya kerangka berfikir akan menjelaskan secara teoritis hubungan antar variable yang akan diteliti.

${ }^{114}$ Dhoni Rozitra dalam Tesis',Evaluasi dan Implementasi Menejemen dalam Pemutakhiran Data Pemilih (Studi pada Pemilihan Legislatif Tahun 2014 oleh Komisi Pemilihan Umum Kota Palembang)", (Program Pasca Sarjana Magister Ilmu Pemerintahan Fakultas Sosial dan Ilmu Politik Universitas Lampung, Bandar Lampung 2017)

${ }^{115}$ Evi Juliansyah (2011) dalam Jurnal, 'Implementasi Kebijakan Pemutakhiran Administrasi Pemilih dalam Pemilihan Gubernur dan Wakil Gubernur',

Jurnal Al-Dustur; VOLUME 1 NO 1, DESEMBER 2018 
$64 \mid$ Delviani

Adapun kerangka fikir yang dimaksud adalah sebagai berikut:

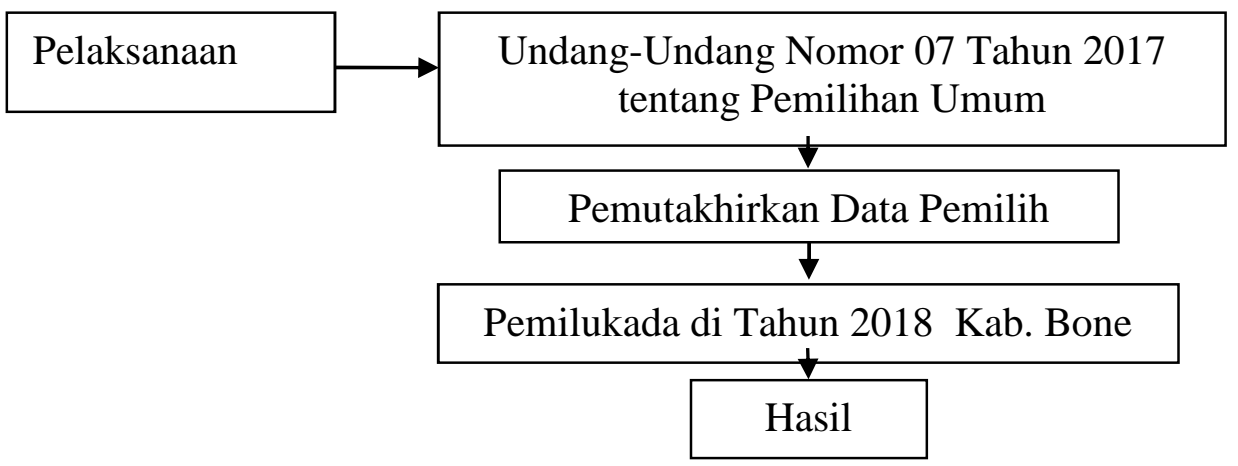

Skema di atas menunjukkan tentang bagaimana pelaksanaan dari UndangUndang Nomor 07 tahun 2017 tentang Pemilihan Umum dalam pemutakhirakan data pemilih dalam pemilukada tahun 2018 di Kabupaten Bone.

\section{Metode Penelitian}

1. Jenis dan Pendekatakan Penelitian

Penelitian ini adalah jenis penelitian lapangan (kualitatif). Penelitian lapangan (kualitatif) adalah penelitian yang langsung berhubungan dengan objek yang akan diteliti untuk memperoleh keterangan langsung menegenai pelaksanaan Undang-Undang Nomor 07 Tahun 2017 tentang Pemilihan Umum dalam pemutakhiran data pemilih dalam pemilukada tahun 2018 di Kabupaten Bone. Berdasarkan permasalahan yang akan dikemukakan, maka penelitian ini menggunakan pendekatan penelitian yaitu sebagai berikut:

a. Pendekatan yuridis normatif adalah jenis pendekatan yang mengacu pada norma hukum yang terdapat dalam peraturan perundang-undangan dan putusan pengadilan serta norma-norma yang hidup dan berlaku di masyarakat. $^{116}$

b. Pendekatan yuridis empiris adalah jenil pendekatan yang dilakukan dengan pendekatan pada realitas hukum di Hasil parakat. Berdasarkan pernyataan tersebut maka peneulis akan memmat realitas yang terkait dengan

${ }^{116}$ Syahruddin Nawi, Penelitian Hukum Normatif Versus Penelitian Hukum Empiris, ([t.Ed]), (Cet. 2; Makassar: PT Umitoha Ukhuwwah Grafika, 2014), h. 7 Jurnal Al-Dustur; VOLUME 1 NO 1, DESEMBER 2018 
pemutakhiran data pemili dalam pemilukada tahun 2018 di Kabupaten Bone yang di lakukan oleh Komisi Pemilihan Umum Kabupaten Bone. ${ }^{117}$

Berdasarkan penjelasan di atas, maka dalam penelitian ini, penulis akan menggunakan desain deskriptif kualitatif yaitu untuk menggambarkan bagaimana pelaksanaan dari Undang-Undang Nomor 07 Tahun 2017 tentang Pemilihan Umum dalam pemutakhiran data pemilih dalam pemilukada Tahun 2018 di Kabupaten Bone.

\section{Lokasi Penelitian}

Penelitian ini berlokasi di Komisi Pemilihan Umum (KPU) Kabupaten Bone karena Komisi Pemilihan Umum itu sendiri merupakan salah satu lembaga yang memiliki peranan penting dalam proses penyelenggara pemilihan umum. termasuk tugas dan kewajibannya dalam memutakhirkan data pemilih dalam Pemilukada tahun 2018 Kabupaten/Kota.

3. Data dan Sumber Data

Menurut Kamus Besar Bahasa Indonesia, data berarti keterangan yang benar dan nyata, atau bahan nyata yang dapat dijadikan sebagai dasar kajian (analisis atau kesimpulan). Data merupakan keterangan-keterangan tentang suatu fakta. Menurut Ndraha dan Prastowo, data berarti bahasa latin date berarti member. ${ }^{118}$ Data dan sumber data adalah subjek dari mana itu diperoleh. ${ }^{119}$ Adapun yang menjadi data dalam penelitian ini adalah sebagai berikut:

a. Data primer

Data primer merupakan data yang diperoleh langsung dari sumber pertama. ${ }^{120}$ Data primer adalah data yang langsung diperoleh peneliti secara langsung di lokasi penelitian melalui sumber pertama (responden atau informasi melalui wawancara) atau melalui hasil pengamatan yang dilakukan sendiri oleh peneliti. ${ }^{121}$ Data yang dimaksud adalah data yang berkenaan dengan pemutakhiran data pemilih. Data yang diperoleh dari Komisi Pemilihan Umum (KPU) Kabupaten Bone.

b. Data sekunder

${ }^{117}$ Syahruddin Nawi, Penelitian Hukum Normatif Versus Penelitian Hukum Normatif, h. 8

118 Andi Prasrowo, Memahami Metode Penelitian Suatu Tinjauan Teoritis dan Praktis, ([t.Ed]), (Cet. 2; Jogjakarta: Ar.Ruzz Media, 2013), h. 30

${ }^{119}$ Suharsini Arikunto, Prosedur Penelitian Suatu Pendekatan Praktek, ([t. Ed]), (Cet. XII; Jakarta: PT Rineka Cipta, 2002), h. 197

120 Amiruddin dan Zainal Asikin, Pengantar Metode Hukum, ([t.Ed]), (Cet. 1; Jakarta: PT Grafindo Persada, 2004), h. 30

${ }^{121}$ Andi Prasrowo, Memahami Metode Penelitian Suatu Tinjauan Teoritis dan Praktis,h. 31 Jurnal Al-Dustur; VOLUME 1 NO 1, DESEMBER 2018 
Data sekunder merupakan data penunjang yang keberadaannya hanya digunakan untuk memperkuat atau melengkapi data primer. ${ }^{122}$ Data sekunder mencakup dokumen-dokumen resmi, buku-buku, hasil penelitian yang berwujud laporan. ${ }^{123}$ Dalam penelitian ini akan menggunakan data sekunder sebagai berikut:

a. Bahan hukum primer

Bahan hukum primer, yaitu bahan hukum yang bersifat autoritatif, artinya mempunyai otoritas, ${ }^{124}$ bahan hukum primer yang digunakan penulis yaitu:

1. Undang-Undang Nomor 7 Tahun 2017 tentang Pemilihan Umum.

2. Undang-Undang Nomor 2 Tahun 2009 tentang Bantuan dan Fasilitas Pemerintah Daerah Dalam Penyelenggaraan Pemilihan Umum

3. Undang-Undang NRI Nomor 2Tahun 2008 tentang Partai Politik

4. Peraturan Komisi Pemilihan Umum Nomor 1-5 tentang Pilkada Serentak Tahun 2017 tentang Tahapan, Program, dan Jadwal Penyelenggaraan Pemilihan Gubernur, dan Wakil Gubernur, Bupati dan Wakil Bupati, dan/atau Walikota dan Wakil Walikota Tahun 2018.

5. Surat Edaran Mahkamah Agung Republik Indonesia Nomor 07-A Tahun 2008 tentang Petunjuk Hakim Khusus Perkara Pidana Pemilihan Umum

b. Bahan hukum sekunder

Bahan hukum sekunder, yaitu bahan yang memberikan penjelasan mengenai bahan hukum primer, dan bahan hukum sekunder yang digunakan penulis yaitu:

a. Buku-buku yang terkait dengan judul

b. Literature yang terkait dengan judul

c. Penelitian terdahulu

c. Bahan hukum tersier

Bahan hukum tersier, yaitu bahan yang memberikan petunjuk maupun penjelasan terhadap hukum primer dan bahan hukum tersier, ${ }^{125}$ dan bahan

122 Nanang Martono, Metode Penelitian Sosial Konsep-Konsep Kunci, ([t.Ed]), (Cet. 1; Jakarta: Rajawali Pers, 2015), h. 67

${ }^{123}$ Amiruddin dan Zainal Asikin, Pengantar Metode Hukum, h. 30

${ }^{124}$ Peter Mahmud Marzuki, Penelitian Hukum, ed. Revisi, ([t.c]; Jakarta: Prenda Media Grup, 2005), h.182.

${ }^{125}$ Amiruddin dan Zainal Asikin, Pengantar Metode Penelitian, h. 32.

Jurnal Al-Dustur; VOLUME 1 NO 1, DESEMBER 2018 
hukum tersier yang penulis gunakan yaitu Kamus Besar Bahasa Indonesia dan Situs Web (Internet).

d. Instrument Penelitian

Intrumen penelitian adalah alat yang digunakan peneliti ketika melakukan proses pengumpulan data. ${ }^{126}$ Dalam penelitian ini akan menggunakan alat yaitu daftar pertanyaan, recorder, handphone, alat tulis, dan yang lainnya kemudian dibuatkan transkripnya dengan mengubah hasil wawancara tersebut dari bentuk rekaman menjadi bentuk tertulis. ${ }^{127}$

a. Dalam metode wawancara, alat yang digunakan penulis adalah daftar pertanyaan, alat tulis dan lain-lain.

b. Dalam metode observasi, alat yang digunakan penulis adalah cek list, kamera dan lain-lain.

e. Teknik Pengumpulan Data

Teknik yang digunakan oleh peneliti dalam proses pengumpulan data dalam penelitian ini yaitu dengan teknik wawancara, observasi (pengamatan), dan dokumentasi

a. Wawancara adalah percakapan yang dilakukan oleh dua pihak, yaitu pewawancara yang mengajukan pertanyaan dan terwawancara yang memberikan jawaban atas pertanyaan tetapi juga dapat diberikan daftar pertanyaan untuk dijawab pada kesempatan lain. Wawancara yang dilakukan bertujuan untuk mendapatkan keterangan atau penjelasan langsung dari narasumber terkait dengan objek penelitian, baik itu wawancara terstruktur maupun wawancara tidak terstruktur.

b. Observasi (pengamatan) adalah teknik pengumpulan data dengan melakukan penelitian terhadap objek yang akan diteliti baik secara langsung maupun tidak langsung. Dalam hal ini yang akan di amati oleh peneliti yaitu dengan melakukan pengamatan langsung secara sistematis di Komisi Pemilihan Umum Kabupaten Bone yang terkait dengan pemutakhiran data pemilih dalam pemilukada tahun 2018 di Kabupaten Bone. Ada beberapa informasi yang akan diperoleh dari hasil observasi

\footnotetext{
${ }^{126}$ Kharuddin Kiramang, dkk, Pedoman Penulisan Makalah dan Skripsi Mahasiswa STAIN Watampone, Ed. Revisi, (Cet. I; Watampone: Pusat Penjamin Mutu, 2016), h. 14.

${ }^{127}$ Muhammad Teguh, Metodologi Penelitian Ekonomi Teori dan Aplikasi, (Ed.1-3;Jakarta: PT.Raja Grafindo Persada, 2005), h. 136-137.

Jurnal Al-Dustur; VOLUME 1 NO 1, DESEMBER 2018
} 
antara lain: ruang (tempat), pelaku, kegiatan, objek, perbuatan, kejadian, waktu, dan lain-lain.

c. Dokumentasi adalah teknik pengumpulan data yang diperoleh dari berbagai dokumen yang menyangkut dengan objek penelitian seperti dokumen-dokumen yang berkaitan dengan pemutakhiran data pemilih. Sifat utama dari data ini tidak terbatas pada ruang dan waktu sehingga dapat memberi peluang kepada peneliti untuk mengetahui hal-hal yang pernah terjadi sebelumnya.

f. Teknik Analisis Data

Data menganalisis data, teknik analisis yang digunakan oleh penulis adalah analisis kualitatif, dengan menggunakan metode sebagai berikut:

a. Induktif yaitu mengambil beberapa fakta yang bersifat khusus untuk diterapkan pada hal-hal yang bersifat umum.

b. Deduktif yaitu mengambil beberapa fakta yang bersifat umum. Yang selanjutnya dianalisis untuk diterapkan ke hal yang bersifat khusus. ${ }^{128}$

\section{Hasil Penelitian}

Berdasarkan hasil wawancara penulis dengan Kepala Bagian dan staf Komisi Pemilihan Umum (KPU) Kabupaten Bone mengenai Pelaksanaan Undang-Undang Nomor 7 Tahun 2017 tentang Pemilihan Umum terhadap Pemutakhiran Data Pemilih dalam Pemilukada di Kabupaten Bone Tahun 2018.

Resmiati selaku Ketua Bagian Program dan Anggaran menyatakan bahwa pemutakhiran data pemilih adalah salah satu kegiatan yang wajib dilakukan oleh Komisi Pemilihan Umum yang bertujuan untuk melakukan pembaharuan data daftar pemilih berdasarkan data Daftar Pemilu Tetap (DPT) dari pemilihan sebelumnya yang di mutakhirkan secara berkelanjutan dan disandingkan dengan data Daftar Penduduk Pemilih Potensial Pemilu (DP4) serta dilakukan pencocokan dan penelitian yang dilaksanakan oleh Komisi Pemilihan Umum (KPU) dengan di bantu oleh Panitia Pemilihan Kecamatan (PPK), Panitia Pemungutan Suara (PPS), dan Petugas Pemutakhiran Data Pemilih (PPDP). Menurut Beliau pelaksanaan Undang-Undang Nomor 7 tahun 2017 tentang Pemilihan Umum dalam Pemutakhiran Data Pemilih telah berjalan sesuai dengan aturan yang telah ditetapkan oleh Undang-Undang akan

${ }^{128}$ Abdullah K, Tahapan dan Langkah-Langkah Penelitian,( Cet. I; t. tp: Luqman Al-Hakim Press, 2013), h. 30 
tetapi karena kurangnya pemahaman dari masyarakat sehingga data yang diperoleh belum sepenuhnya akurat. ${ }^{129}$

Hal serupa juga disampaikan oleh Rita Febrianti selaku Kepala Bagian Tekhnis Pemilu dan Humas yang menyatakan bahwa terkait dengan pelaksanaan Undang-Undang Nomor 7 Tahun 2017 tentang Pemilihan Umum dalam Pemutakhiran Data Pemilih telah berjalalan sesuai dengan yang ditetapkan oleh Undang-Undang akan tetapi pada dasarnya tujuan dari pada pemutakhiran data pemilih itu sendiri belum sepenuhnya terpenuhi karena masih ditemui beberapa kendala seperti, pada saat proses pemutakhiran data pemilih dilakukan banyak masyarakat yang sedang tidak berada di rumah sehingga Petugas Pemutakhiran Data Pemilih (PPDP) harus bekerja dua kali. ${ }^{130}$

Hal sama juga di sampaikan oleh saudarai Darniati selaku Panitia Pemungutan suara sekaligus anggota Petugas Pemutakhiran Data Pemilih menyatakan bahwa peraturan yang ditetapkan oleh Undang-Undang Nomor 7 tahun 2017 tentang Pemilihan Umum sudah sangat baik hal itu terbukti dari berbagai bimbingan tekhnis yang di lakukan oleh Komisi Pemilihan Umum sejak saya diangkat menjadi anggota PPS dan PPDP akan tetapi selaku anggota Panitia Pemungutan Suara sekaligus Petugas Pemutakhiran Data Pemilih harus bekerja ekstra karena proses pemutakhiran data pemilih dilakukan dengan cara mengunjungi rumah warga satu persatu akan tetapi pada saat proses pemutakhiran data dilakukan masih banyak masyarakat yang sedang merantau ke luar kota dan tidak diketahui kapan akan kembali dan masih banyak masyarakat yang tidak memiliki Kartu Tanda Penduduk Elektronik (E-KTP) khususnya bagi pemilih pemula. ${ }^{131}$

Pernyataan yang sama juga disampaikan oleh $\mathrm{Hj}$. A. Nurhaedah Bali selaku Sekertaris Panitia Pemungutan Suara (PPS) Kecamatan Tanete Riattang Barat menyatakan bahwa aturan pemerintah terkait dengan Undang-Undang Nomor 7 tahun 2017 tentang Pemilihan Umum ini sudah sangat baik bimbingan dan pantauan dari Komisi Pemilihan Umum tak henti-hentinya dilakukan demi lancarnya proses pemutakhiran data pemilih ini, akan tetapi apa yang kami temui di lapangan sangat berbeda dengan yang apa yang kami pahami selama ini rupanya selain bekal ilmu

${ }^{129}$ Resmiati, selaku Ketua Bagian Program dan Anggaran Komisi Pemilihan Umum Kabupaten Bone. Wawancara oleh Penulis Kmis, 24 Mei 2018

${ }^{130}$ Rita Febrianti, selaku Kepala Bagian Pemilu dan Humas Komisi Pemilihan Umum Kabupaten Bone. Wawancara oleh Penulis Kamis, 24 Mei 2018

${ }^{131}$ Darniati, selaku anggota PPS dan PPDP desa Paccing, Kecamatan Awampone. Wawancara oleh Penulis, Jumat 25 Mei 2018 
yang cukup kami juga harus lebih teliti pada saat proses pemutakhiran dilakukan karena banyaknya masyarakat yang kurang bahkan tidak memahami sehingga pada saat proses pemutakhiran berlangsung masih banyak warga masyarakat yang meninggalkan rumah, tidak memiliki identitas yang lengkap seperti tidak memiliki Kartu Keluarga dan KTP Elektronik sehingga pemutakhiran data pemilih ini tidak bisa berjalan sesuai dengan waktu yang telah ditentukan. ${ }^{132}$

Demikian pula pernyataan dari saudari Yusna Amanda Putri selaku anggota Petugas Pemutakhiran Data Pemilih (PPDP) Desa Matuju Kecamatan Awampone yang menyatakan bahwa selaku masyarakat yang sadar hukum mengenai UndangUndang Nomor 7 tahun 2017 tentang Pemilihan Umum sudah baik akan tetapi terkadang teori yang kita pahami saling bertolak belakang dengan apa yang di peroleh pada saat berada di lapangan. Salah satu kendala yang dihadapi pada saat proses pemutakhiran data pemilih ini berlangsung selain masyarakat yang tidak memiliki Kartu Tanda Penduduk (E-KTP) kami selaku anggota Petugas Pemutakhiran Data Pemilih juga mengalami kesulitan pada saat pencocokan data daftar pemilih. ${ }^{133}$

Demikian pula menurut saudara Ahmad, selaku anggota Petugas Pemutakhiran Data Pemilih (PPS) Kelurahan Mampotu, Kecamatan Amali menyatakan bahwa proses pemutakhiran data pemilih ini tidak berjalan sesuai dengan waktu yang ditentukan karena sulitnya melakukan pencocokan data pada saat coklit dilakukan. $^{134}$

Berdasarkan pernyataan di atas menunjukkan bahwa penerapan UndangUndang Nomor 7 Tahun 2017 tentang Pemilihan Umum dalam pemutakhiran data pemilih sudah berjalan dengan baik akan tetapi pada tahap pelaksanaannya masih dijumpai beberapa kendala diantaranya adanya masyarakat yang tidak memiliki identitas yang lengkap adanya sejumlah masyarakat yang tidak berada di rumah pada saat proses pemutakhiran data dilakukan dan sulitnya pencocokan data daftar pemilih pada pemilihan sebelumnya.

${ }^{132}$ Hj. A. Nurhaedah Bali, selaku Sekertaris Panitia Pemungutan Suara (PPS) Kecamatan Tanete Riattang Barat. Wawancara oleh Penulis Senin 28 Mei 2018

${ }^{133}$ Yusna Amanda Putir, selaku anggota Petugas Pemutakhiran Data Pemilih (PPDP) Desa Matuju Kecamatan Awampone. Wawancara oleh Penulis, Jumat 01 Juni 2018

134 Ahmad, selaku Anggota Petugas Pemutakhiran Data (PPDP) Kelurahan Mampotu, Kecamatanm Amali. Wawancara oleh Penulis, Minggu 3 Juni 2018

Jurnal Al-Dustur; VOLUME 1 NO 1, DESEMBER 2018 


\section{Kesimpulan}

Setelah penulis mengemukakan uraian secara terperinci tentang masalahmasalah sesuai dengan topik pembahasan, maka tibalah pada uraian terakhir penulis terkait dengan pelaksanaan Undang-Undang Nomor 7 tahun 2017 tentang Pemilihan Umum terhadap Pemutakhiran Data Pemili di Kabupaten Bone jika merujuk pada aturan Undang-Undang seharusnya berjalan dengan baik akan tetapi pada proses pelaksanaannya masih dijumpai beberapa kendala diantaranya masih banyaknya masyarakat yang tidak memiliki Kartu Tanda Penduduk Elektronik (E-KTP) dan adanya masyarakat yang sedang tidak berada di rumah atau tempat domisilinya pada saat proses pemutakhiran data pemilih dilakukan serta sulitnya melakukan pencocokan data daftar pemilih sehingga pemutakhiran data pemilih tidak berjalan sesuai dengan waktu yang telah ditentukan.Selain itu, kurangnya pemahaman masyarakat terhadap pentingnya penggunaan hak pilih pada saat pemilihan berlangsung juga menjadi faktor pemicu pelaksanaan Undang-Undang Nomor 7 Tahun 2017 tentang Pemilihan Umum terkait dengan pemutakhiran datra pemilih ini tidak berajalan dengan sebagai mana mestinya.

\section{Referensi}

Arake,Lukman Benarkah Islam Mengajarkan Politik, Cet. 1; (Samata-Gowa: Gunadarma Ilmu, 2017), h. 243

Al- Mawardi, Imam. Penerjemah Padi Bahr. Ahkam As-Sultaniyah

Abdullah, Rosali. Pelaksanaan Otonomi Luas Dengan Pemilihan Kepala Daerah Secara Langsung. ([t. Ed]). (([t.C]); Jakarta: PT Grafindo Persada, 2005).

Aminah, Siti. Kuasa Negara Pada Ranah Politik Lokal. Ed. 1. (Cet. 1; Jakarta: PT Fajar Interpratama Mandiri, 2014).

Amiruddin, dan Zainal Asikin. Pengantar Metode Hukum. ([t.Ed]). (Cet. 1; Jakarta: PT Grafindo Persada, 2004).

Arikunto, Suharsini, Prosedur Penelitian Suatu Pendekatan Praktek. ([t. Ed]). (Cet. XII; Jakarta: PT Rineka Cipta, 2002).

Ariwibowo. Negara Pemilihan Umum dan Demokrasi. ([t.Ed]). (Cet. 1; Jakarta: Lembaga Studi dan Advokasi Masyarakat, 2005).

Asad, Muhammad Beberapa Pandangan Tentang Pemerintahan Islam. (Cet. I; Bandung: Mizan, 1983)

Asshiddiqie, Jimly Bung Hatta Bapak Kedaulatan Rakyat. ([t.c]; Jakarta: Yayasan Bung Hatta, 2002) 
72 | Delviani

Asshiddiqie, Jimly, Islam dan Kedaulatan Rakyat, (Cet. I; Jakarta: Gema Insani Press, 1995)

Departemen Agama RI, Al-Qur'an dan Terjemahannya, Q.S. An-Nisa: 58

Fadjar, A Mukhti. Pemilu, Perselisihan Hasil Pemilu dan Demokrasi, ([t.Ed]), (Cet. 1; Malang: Stara Pers, 2013).

Fadjar, A.Mukthie Pemilu dan Demokrasi, (Cet. I; Setara Press: Malang, 2013)

Gatara A, Said. Ilmu Politik Memahami dan Menerapkan, ([t.Ed]), (Cet. 1; Bandung: Pustaka Setia, 2008).

Gatara, A. Sahid Ilmu Politik Memahami dan Menerapkan, (Cet. I; Bandung: Pustaka Setia, 2008) 